\title{
Assessment of Decline in Melon Yield and its Contribution to Young Farmers' Diversification into Watermelon Farming in Oyo State, Nigeria.
}

\section{Evaluación de la disminución en el rendimiento del melón y su contribución a la diversificación de los agricultores jóvenes en la agricultura de sandía en el estado de Oyo, Nigeria.}

\author{
Oyediran Wasiu Oyeleke ${ }^{1}$, and Omoare Ayodeji Motunrayo ${ }^{2}$
}

1- Department of Agricultural Extension and Rural Development, Federal University of Agriculture, Abeokuta, Ogun State, Nigeria.

2- Department of Agricultural Education, Federal College of Education, Abeokuta, Ogun State, Nigeria.

\section{ABSTRACT}

Melon is a popular economic cucurbit in Southwest, Nigeria. In recent time, many young farmers are shifting from melon to watermelon farming due to poor yield and low monetary returns. Hence, this study was carried out to assess decline in melon yield and its contribution to young farmers' diversification into watermelon farming in Oyo state, Nigeria. Purposive sampling technique was used in selecting 75 respondents from five villages in Ibarapa block of the Oyo State Agricultural Development Project (ADP). Data collected were analyzed using descriptive statistics and Pearson Product Moment Correlation (PPMC). Results show that majority of the respondents (77.3\%) were between $31-40$ years of age and $46.7 \%$ had secondary school education. Most of the respondents ( $80 \%$ ) cultivated more than 3 ha of land for watermelon. Majority of the respondents (74.7\%) intercropped melon with other crops while watermelon was cultivated as a sole crop. None of the respondents either grew improved melon seeds (certified seeds) or applied fertilizers but all respondents cultivated treated watermelon seeds, applied fertilizers and agro-chemicals in watermelon farming. The average yields of melon fell from $376.53 \mathrm{~kg} / \mathrm{ha}$ in 2009 to $280.70 \mathrm{~kg} / \mathrm{ha}$ in 2011. However, the respondents were shifting into watermelon production because of available quality seeds and its early maturity, easy harvest and high sales. There was a significant relationship between melon output and young farmers' diversification to 
watermelon in the study area at $p<0.05$. The study concluded that decline in the melon yield discouraged youth to continue melon farming in the study area. It is hereby recommended that certified melon seeds should be made available while extension service providers should provide training support for the young farmers in order to reposition and boost melon production in the study area.

Keywords--decline, melon yield, contribution, watermelon, diversification, young farmers.

\section{RESUMEN}

El melón es una cucurbitáceas económica popular en el sudoeste de Nigeria. En los últimos tiempos, muchos jóvenes agricultores están pasando del melón al cultivo de la sandía debido a su bajo rendimiento y sus bajos ingresos monetarios. Por lo tanto, este estudio se llevó a cabo para evaluar la disminución en el rendimiento del melón y su contribución a la diversificación de los jóvenes agricultores en la agricultura de sandía en el estado de Oyo, Nigeria. La técnica de muestreo intencional se utilizó para seleccionar a 75 encuestados de cinco aldeas en el bloque Ibarapa del Proyecto de Desarrollo Agrícola del Estado de Oyo (ADP). Los datos recolectados se analizaron usando estadística descriptiva y Pearson Product Moment Correlation (PPMC). Los resultados muestran que la mayoría de los encuestados (77.3\%) tenían entre 31-40 años de edad y 46.70\% tenían educación secundaria. La mayoría de los encuestados (80\%) cultivaron más de 3 hectáreas de tierra para sandía. La mayoría de los encuestados $(74,7 \%)$ cultivaron melón intercalado con otros cultivos, mientras que la sandía se cultivó como un único cultivo. Ninguno de los encuestados cultivó semillas mejoradas de melón (semillas certificadas) o fertilizantes aplicados, pero todos los encuestados cultivaron semillas de sandía tratadas, fertilizantes aplicados y agroquímicos. Los rendimientos promedio de melón cayeron de $376.53 \mathrm{~kg} / \mathrm{ha}$ en 2009 a $280.70 \mathrm{~kg} /$ ha en 2011. Sin embargo, los encuestados estaban cambiando a la producción de sandía debido a las semillas disponibles de calidad y su madurez temprana, fácil cosecha y altas ventas. Hubo una relación significativa entre el rendimiento del melón y la diversificación de los jóvenes agricultores a la sandía en el área de estudio en $\mathrm{p}<0.05$. El estudio concluyó que la disminución en el rendimiento de melón desanimó a los jóvenes a continuar cultivando melones en el área de estudio. Se recomienda que las semillas de melón certificadas estén disponibles, mientras que los proveedores de servicios de extensión deberían proporcionar apoyo de capacitación a los jóvenes agricultores para reubicar e impulsar la producción de melón en el área de estudio.

Palabras clave: disminución, rendimiento del melón, contribución, sandía, diversificación, jóvenes agricultores. 


\section{INTRODUCTION}

Melons (Citrillus colocynthis L.) and watermelons (Citrullus vulgaris L.) are two common economic cucurbits in Southwest, Nigeria (Oyeridan et al., 2014). Melon (Citrullus colcynthis) also known as honeydew. It is an annual crop planted twice in a year, as an early and late season crop due to the bimodal nature of the raining season in the area. Melon (egusi) belongs to the family of cucurbitaceae and it is planted for its seed oil (Sodiya et al., 2014). Egusi is known for the richness found in its seeds. In the savannas of southwestern Nigeria, the seeds are prized for their flavour and for the powder they produce when dried and ground up. The pungent powder spices up soups. On the other hand watermelon (Citrullus lanatus) is grown commercially in areas with long frost free warm periods (Prohens \& Nuez, 2008). China, Turkey, Iran, Brazil, United States, Egypt and Russian Federation are the major watermelon producers (FAO, 2010). Two decades ago watermelon was introduced into rural farming system in Nigeria, and it grows well both in the humid and drier savanna agro-ecologies. The largest production of the crop comes from the northern part of Nigeria where suitable agro-ecology is found (Wani et al., 2008). Watermelon is utilized for the production of juices, nectars and fruit cocktails, etc. in advanced countries (Oladoja et al., 2006). In rural farming system of developing countries melon production offer more post-harvest opportunities than watermelon but the various activities involved are labour intensive. For instance, after melon pods are harvested on the farm, other postharvest activities like gathering and breaking of the pods, fermentation, scooping of the seeds from the pods, washing and sun-drying will still be carried out before the seeds can be made available for marketing or consumption. Whereas, watermelon production terminated at harvest by hand picking the pods and packed into the vehicle for marketing or immediate consumption. Based on tedious nature of melon production and low yield many young and adult male farmers in southwest, Nigeria are diversifying into watermelon production with hope of generating more income for better living. However, few or no research studies have been carried out to look into this trend and provide possible way out to promote and sustain affected crop (melon). It is against this background that this study becomes pertinent to bridge the information gap by assessing the effect of decline in melon yield on young farmers' diversification into watermelon farming in Oyo State, Nigeria.

The aims of the present study were 1) describe the socio-economic characteristics of respondents in the study area, 2) compare cropping systems adopted for melon with watermelon in the study area, 3) investigate trend of melon yield before shifting to watermelon in the study area, 4) ascertain reasons for shifting to watermelon production by 
respondents in the study area. As hypothesis it proposed the absence of significant relationship between decline in melon output and young farmers' diversification to watermelon in the study area.

\section{MATERIALS AND METHODS}

The study was carried out in Oyo State, Nigeria. Population of the study was all melon farmers who had shifted into watermelon farming. A multi stage sampling technique was used in selecting respondents for this study. There are four major Agricultural Development Programme (ADP) zones in Oyo State namely; Ibadan/Ibarapa, Oyo, Ogbomosho and Saki. Ibadan/Ibarapa zone was purposively selected based on the a priori information that virtually every rural household in the communities cultivated melon and watermelon production, this represents $25 \%$ of total zones. This zone is particularly known for horticultural crop production and a large percentage of the inhabitants are farmers. The second stage was random selection of one block out of eight blocks (Ibarapa Central), this represents $12.5 \%$ of the total blocks in the selected zone. In the third stage, a simple random sampling technique was used to select five villages from the selected block. The final stage was purposive selection of 15 melon farmers who are now cultivating watermelon from each of selected village using snowball technique. This gives a total of 75 respondents as sample size for this study.

The instrument used for the data collection was subjected to face validity by consulting experts in the field of Agricultural Extension and Rural Development. Items found ambiguous were removed. Test re-test was carried out with twenty (20) watermelon farmers in Iserin community of Oke-Ogun at an interval of two weeks to ascertain the reliability of the instrument. A reliability coefficient of 0.88 was obtained which is above the reliability coefficient of 0.75 . Hence, the instrument used for this study was reliable. Descriptive statistics such as percentage, mean and frequency count and Pearson Product Moment Correlation were used for data analysis.

\section{RESULTS AND DISCUSSION}

Socio-economic characteristics of respondents: the result of the analysis in Table 1 shows that the mean age of the respondents was 35.10 years. Majority of the respondents (77.30\%) were between 31-40 years old while few (9.30\%) were above 41 years of age. This reveals the presence of young and middle aged individuals who are known to be active 
and innovative. This is in line with Oladoja et al. (2006) which states that most Nigerian farmers are within this age group and are economically active part of the population. Majority of the respondents (96\%) were males while only $4 \%$ were females. This indicates the dominance of male folk in melon and watermelon production in the study area. This is attributed to the fact that men are more involved in cultivation and harvesting activities while women are mainly occupied in the post-harvesting activities and marketing of farm produce.

Table 1: Distribution of respondents based on the respondents' socio-economic characteristics $(n=75)$

\begin{tabular}{llll}
\hline Variables & Frequency & Percentage & Mean \\
\hline Age (years) & 10 & 13.30 & 35.10 \\
$\geq 30$ & 58 & 77.30 & \\
$31-40$ & 07 & 9.30 & \\
41 and above & & & \\
Sex & 72 & 96.00 & \\
Male & 03 & 4.00 & \\
Female & & & \\
Educational status & 05 & 6.70 & \\
No formal education & 29 & 38.60 & \\
Primary education & 35 & 46.70 & \\
Secondary education & 06 & 8.00 & \\
Tertiary education & & & \\
Farming experience (years) & 18 & 24.00 & \\
$\geq 5$ & 46 & 61.30 & \\
6 - 10 & 11 & 20.00 & \\
11 and above & 60 & 80.00 & \\
Farm size (ha) & & & \\
$1-2$ & & & \\
3 and above & & & \\
\hline
\end{tabular}

Source: Field Survey, 2015

This finding agrees with Odebode (2007) who reported that adult males are engaged in land clearing, planting and weeding, while adult females carried out the seed selection and post-harvest practices in melon production. Many of the respondents $(46.70 \%)$ had 
secondary school education while $38.60 \%$ attended primary school. Only $6.70 \%$ did not have formal education. This shows that the farmers had some level of literacy in the study area which may in turn affect the rate of adoption of modern farming practices. This is in consonance with Yahaya and Olajide (2002) who noted that educational level of farmers affected their preference for printed materials. The mean year of farming experiences was 7.53 years. The result also indicates that $61.30 \%$ of the respondents had grown melon for 6-10 years while14.70\% had been in melon cultivation for more than 11 years before shifting to watermelon farming. This further shows that melon production and other horticultural crops are not new to the farmers in the study area. The mean farm size was 3.10 ha. Majority of the respondents (80\%) cultivated more than 3 ha of land while $20 \%$ cultivated 1-2 ha. This shows that most of the respondents are peasant farmers.

Comparative of melon and watermelon cropping practices

In Table 2, the result shows that some of the respondents $(25.30 \%)$ cultivated melon as sole crop while majority of the respondents $(74.70 \%)$ practised intercropping. The reasons given for intercropping melon with other crops were to prevent against total crop failure and maximize land and labour utilization. These results corroborate the findings of Ayoola and Adeniran (2006), which states that intercropping are practised to enhance better utilization of land, labour and capital and to ensure food security in situations of a crop failure with the intent to maximize yield and profit. The result also shows that none of the respondents either grew improved seeds (certified seeds) or applied fertilizers. Only few of the respondents $(16 \%)$ sprayed the melon farms with agro-chemicals to control pest and diseases. These crude practices could not be unconnected with the poor information linkage on improved farming practice from agricultural extension service because most of the farmers still believe that melon can withstand any condition and does not require application of fertilizers and agro-chemicals. On the other hand about ninety-five percent of the respondents ( $94.70 \%)$ grown watermelon as a sole crop while only few of the respondents $(3.30 \%)$ did intercropping with maize and cassava. Meanwhile all the respondents (100\%) planted improved seeds (certified), applied fertilizers and used agro-chemicals to control pest and diseases. Farmers treated watermelon with caution because of its exotic nature (imported seeds) unlike melon.

Decline in yield of melon $(\mathrm{kg} / \mathrm{ha})$ : the yield of melon has drastically reduced according to the field survey carried out between 2009 and 2011 cropping years in the study area. The estimated average yield for the 2009, 2010 and 2011 cropping seasons were put at $376.53 \mathrm{~kg} / \mathrm{ha}, 323.95 \mathrm{~kg} / \mathrm{ha}$ and $280.70 \mathrm{~kg} / \mathrm{ha}$ respectively. Many $(40.70 \%)$ of the respondents harvested $401-500 \mathrm{~kg} / \mathrm{ha}$ in 2009 while $21.80 \%$ and $4.60 \%$ obtained 
similar yield in 2010 and 2011 respectively. However, some (6.90\%) recorded the lowest yield (less than $200 \mathrm{~kg} / \mathrm{ha}$ ) in 2011 while $2.30 \%$ and $0.5 \%$ got the similar yield in 2010 and 2009 respectively. This confirms the decline in melon yield over the years. However, the results obtained on the field contradicted the expected yields of $1100 \mathrm{~kg} / \mathrm{ha}$ in Nigeria as reported by van der Vossen et al. (2004). This variation may not be unconnected with the traditional farming practices that predominant in melon production. Consequently, the effect of low productivity in melon production is noticed in the southwest region of Nigeria as the large proportion of melon sold in the markets are brought from the northern parts of the country to cushion the effect of the decline and as such melon marketing is gradually dominated by Hausas' men using wheel barrows while the Yoruba women involvement in melon business is gradually diminishing Oyediran (2013)

Table 2: Comparative of melon and watermelon cropping practices $(n=75)$

\begin{tabular}{lll}
\hline Cropping system & Melon & Watermelon \\
\hline Sole cropping & 25.30 & 94.70 \\
Mixed cropping & 74.70 & 3.30 \\
Use of quality seeds (certified) & 0.00 & 100.0 \\
Fertilizer application & 0.00 & 100.0 \\
Sprayed with insecticides & 16.0 & 100.0 \\
\hline
\end{tabular}

Source: Field Survey, 2015

Table 3: Distribution according to decline in melon yield $(\mathrm{kg} / \mathrm{ha})$

\begin{tabular}{llll}
\hline $\begin{array}{l}\text { Years } \\
\text { Yield (kg/ha) }\end{array}$ & 2009 & 2010 & 2011 \\
\hline $101-200$ & 4.00 & 12.00 & 8.00 \\
$201-300$ & 9.30 & 26.70 & 66.70 \\
$301-400$ & 29.30 & 38.70 & 20.00 \\
$401-500$ & 50.70 & 22.00 & 5.30 \\
501 above & 6.70 & 0.00 & 0.00 \\
Average yield (kg/ha) & 376.53 & 323.95 & 280.70 \\
\hline
\end{tabular}

Source: Field survey, 2015

Reasons for diversification to watermelon production: the result in Table 4 shows the reasons why the young farmers are leaving melon cultivation to watermelon farming. Almost all of the respondents strongly agreed that watermelon production is not tedious 
since it does not require further processing after harvest $(\overline{\mathrm{X}}=4.99 ; \mathrm{S} . \mathrm{D}=0.12)$ unlike melon. It was also indicated that watermelon was easy to harvest $(\bar{X}=4.96 ; S . D=0.20)$, reached maturity very early $(\overline{\mathrm{X}}=4.95$; S.D $=0.23$ ), and quality seeds were available for its cultivation $(\bar{X}=4.91$; S.D $=0.29$ ). Moreover, the respondents revealed that watermelon was very easy to transport to market $(\bar{X}=4.81$; S.D $=0.51)$, require few hands at harvest $(\bar{X}=4.73 ;$ S.D $=0.72)$, high market demand $(\bar{X}=4.79 ; S . D=0.55)$ and sales $(\bar{X}=4.89$; S.D $=0.31)$. However, many of the respondents strongly disagreed that watermelon is easy to cultivate $(\overline{\mathrm{X}}=1.95 ; \mathrm{S} . \mathrm{D}=1.33)$, require lesser inorganic fertilizer $(\overline{\mathrm{X}}=1.84 ; \mathrm{S} . \mathrm{D}=$ 1.20) and agrochemicals ( $\bar{X}=1.47 ; S . D=0.95)$. It was also reported that watermelon is highly susceptible to crop failure $(\overline{\mathrm{X}}=1.61$; S.D $=1.04)$ due to its susceptibility to pest and diseases and weather vagaries compare to melon. Watermelon requires thorough agronomic practices from seed selection, land preparation, fertilizer and agro-chemicals application, harvesting and sorting unlike melon. Any attempt to neglect these practices in watermelon will result to a total crop failure.

Table 4: Reasons for diversification to watermelon production by the youths $(n=75)$

\begin{tabular}{llllllll}
\hline Statements & SA & A & U & D & SD & $\bar{X}$ & S.D. \\
\hline Availability of planting materials & 90.7 & 9.3 & 0.0 & 0.0 & 0.0 & 4.91 & 0.29 \\
Early maturing & 94.7 & 5.3 & 0.0 & 0.0 & 0.0 & 4.95 & 0.23 \\
Easy to cultivate & 8.0 & 10.7 & 5.3 & 17.3 & 58.7 & 1.95 & 1.33 \\
Require lesser inorganic fertilizer & 4.0 & 13.3 & 0.0 & 28.0 & 54.7 & 1.84 & 1.20 \\
application & & & & & & & \\
Require lesser spray & 0.0 & 10.7 & 0.0 & 13.3 & 76.0 & 1.47 & 0.95 \\
agrochemicals & & & & & & & \\
Cost of production is low & 48.0 & 38.7 & 0.0 & 8.0 & 5.3 & 4.12 & 1.15 \\
Easy to harvest & 96.0 & 4.0 & 0.0 & 0.0 & 0.0 & 4.96 & 0.20 \\
Less tedious processing & 98.7 & 1.3 & 0.0 & 0.0 & 0.0 & 4.99 & 0.12 \\
Few hands (labour) are required & 84.0 & 9.3 & 0.0 & 6.7 & 0.0 & 4.73 & 0.72 \\
Ease of transportation & 86.7 & 8.0 & 5.3 & 0.0 & 0.0 & 4.81 & 0.51 \\
Risk of crop failure is relatively & 0.0 & 12.0 & 5.3 & 16.0 & 66.7 & 1.61 & 1.04 \\
low & & & & & & & \\
It can be stored for long & 60.0 & 20.0 & 0.0 & 13.3 & 6.7 & 4.13 & 1.32 \\
Readily market & 85.3 & 8.0 & 6.7 & 0.0 & 0.0 & 4.79 & 0.55 \\
High sales & 89.3 & 10.7 & 0.0 & 0.0 & 0.0 & 4.89 & 0.31 \\
\hline
\end{tabular}

Source: Field Survey, 2015. S.D.-Standard Deviation, $\overline{\mathrm{X}}$ - Mean

SA - Strongly Agree, A - Agree, U - Undecided, D - Disagree, SD - Strongly Disagree 
Test of relationship between melon output and youth diversification to watermelon The hypothesis $\left(\mathrm{H}_{01}\right)$ : "There is no significant relationship between decline in melon output and young farmers' diversification to watermelon in the study area". This was tested using Pearson Product Moment Correlation (PPMC) and the result is presented in Table 5. The result indicates that there was a positive and significant relationship between melon output $(r=0.87, p<0.05)$ and young farmers' diversification to watermelon in the study area. The null hypothesis $\left(\mathrm{H}_{0}\right)$ is therefore rejected and the alternate hypothesis $\left(\mathrm{H}_{1}\right)$ that "there was a significant relationship between decline in melon output and young farmers' diversification to watermelon in the study area" is accepted.

Table 5. Relationship between melon output and young farmers' diversification to watermelon

\begin{tabular}{llll}
\hline Variable & $\mathrm{r}$ & $\mathrm{p}$-value & Decision \\
\hline Melon output & 0.87 & 0.02 & Significant
\end{tabular}

Source: Field Survey, 2015

As conclusion, this study concluded that while improved cropping practices were used for watermelon, traditional methods were predominantly used for melon. Hence, production pattern adopted for melon had direct bearing on the decline in melon yield, the development which discouraged young farmers to continue melon farming. Consequently, the young farmers are continuously diversifying into watermelon farming because of the decline in melon yield. Certified seeds of watermelon that have higher output were also available in the study area.

For young farmers to return into melon farming it is hereby recommended that 1 ) extension service providers should teach the young melon farmers an improved farming system that can guarantee better output in the study area; 2) government should encourage development of new melon hybrid by adequately funding research institutes and extension service; and 3) crop scientists and breeders should as well put in their expertise to produce improved melon seeds that are viable, high yielding and resistant to drought, pest and diseases.

\section{REFERENCES}

Ayoola, O. T. \& Adeniyan, O. N. 2006. Influence of poultry manure and NPK fertilizer on yield and components of crops under different cropping system in southwest, Nigeria. African J. Biotechnol. 5: 1386-1392.

FAO - Food and Agriculture Organisation, 2010. The State of food Insecurity in World 2010. 
http://www.fao.org/docrep/013/i1683e/ i1683e.pdf. Accessed 14th June, 2012.

Odebode, S. O. 2007. Gender Participation of Melon Farmers in Ibarapa Area of Oyo State, Nigeria. Agricult. J., 2: 108-111.

Oladoja, M.A., Adisa, B.O. \& Ahmed-Akinola, A. A. 2006. Effectiveness of communication methods used in information delivery to cocoa farmers in Oluyole Local Government of Oyo State. The Ogun J. Agricult. Sci.. 4: 78-88.

Oyediran, W.O. 2013. Factors Affecting melon (Citrillus colocynthis) production in Oyo State, Nigeria. Unpublished M. Agric. Thesis, Department of Agricultural Extension and Rural Development, Federal University of Agriculture, Abeokuta, Nigeria, 145p

Oyediran, W.O., Sodiya, C.I. \& Omoare, A.M. 2014. Determinants of melon production in Iseyin Local Government Area of Oyo State, Nigeria. Sch. J. Agricult. Vet. Sci., 1: $42-49$.

Prohens, J., \& Nuez, F. 2008. Vegetables I: Handbook of Plant Breeding. New York. Springer. pp. 381-418.

Sodiya, C.I. \& Oyediran, W.O. 2014. Contributions of melon production to livelihood sustainability of rural farming households in Oyo State, Nigeria. J. Biol., Agricult. Healthcare, 4: 8 - 18.

Van der Vossen, H.A.M., Denton, O.A. \& El-Tahir, I.M. 2004. Citrillus lanatus. In: Grubben, G. J. H and Denton, O. A. Plant resources of Tropical Africa 2 Vegetables. Wageningen. The Netherlands; CTA, Leiden, the Netherlands: Backhuys Publishers, pp 185-191.

Wani, A.A., Kaur, D., Ahmed, I., \& Sogi, D.S. 2008. Extraction optimization of watermelon seed protein using response surface methodology. LWT Food Sci. Technol. 41 (8): 1514 - 1520.

Yahaya, M.K. \& Olajide, B.R. 2002. Comparative Analysis of conventional and traditional media for the utilization of entertainment-education format for Agricultural Dissemination in Nigeria. J. Soc. Sci., 7, 1-7.

Received: $12^{\text {th }}$ November 2017

Accepted: $13^{\text {th }}$ March 2018 
Sustainability, Agri, Food and Environmental Research, (ISSN: 0719-3726), 6(1), 2018: 18-27 http://dx.doi.org/10.7770/safer-V6N1-art1318 